\title{
Speaking to the Eye: The wild boar from San Rossore
}

\author{
LIV EMMA THORSEN*
}

\begin{abstract}
The article discusses a taxidermy work of a wild boar fighting two dogs. The tableau was made in 1824 by the Italian scientist Paolo Savi, director of the Natural History Museum in Pisa from 1823-1840. The point of departure is the sense of awe this brilliantly produced tableau evokes in the spectator. If an object could talk, what does the wild boar communicate? Stuffed animals are objects that operate in natural history exhibitions as well in several other contexts. They resist a standard classification, belonging to neither nature nor culture. The wild boar in question illustrates this ambiguity. To decode the tale of the boar, it is established as a centre in a network that connects Savi's scientific and personal knowledge, the wild boar as a noble trophy, the development of the wild boar hunt in Tuscany, perceptions of the boar and the connection between science and art.
\end{abstract}

Key words: Natural history museum, taxidermy, wild boar, wild boar hunt, the wild boar in art, ornithology, natural history in Tuscany, Museo di Storia Naturale e del Territorio, Paolo Savi.

In 1821, a giant male wild boar was killed at San Rossore, the hunting property of the Grand Duke of Toscana. It was killed during a hunt arranged in honour of prominent guests of Ferdinand III. Under the skilled hands of Paolo Savi, the wild boar was prepared and placed in a new hunting scene. The tableau became an eye-catching attraction in Galleria Pisana, then housing the university's natural history collections. It was on display here from 1824 to 1981 when the collections were packed and moved away from the old university area in the centre of Pisa to Certosa di Calci. ${ }^{1}$ Botany was all that was left in the town.
There is a complex history to this wild boar. We have to understand the important role this species played in Italian and European hunting tradition, the link between natural history illustrations and art and the porous boundaries between the museum and the society outside its walls. Together with four other dramatic tableaux - a condor feeding on a donkey foal, the fight between a pair of wolves and a shepherd dog, a lioness that has brought down an antelope, and a single Bengal tiger the wild boar and the dogs form a central axis in Sala Storica. Along the walls are arranged wax models, conches, prepared intestines, 


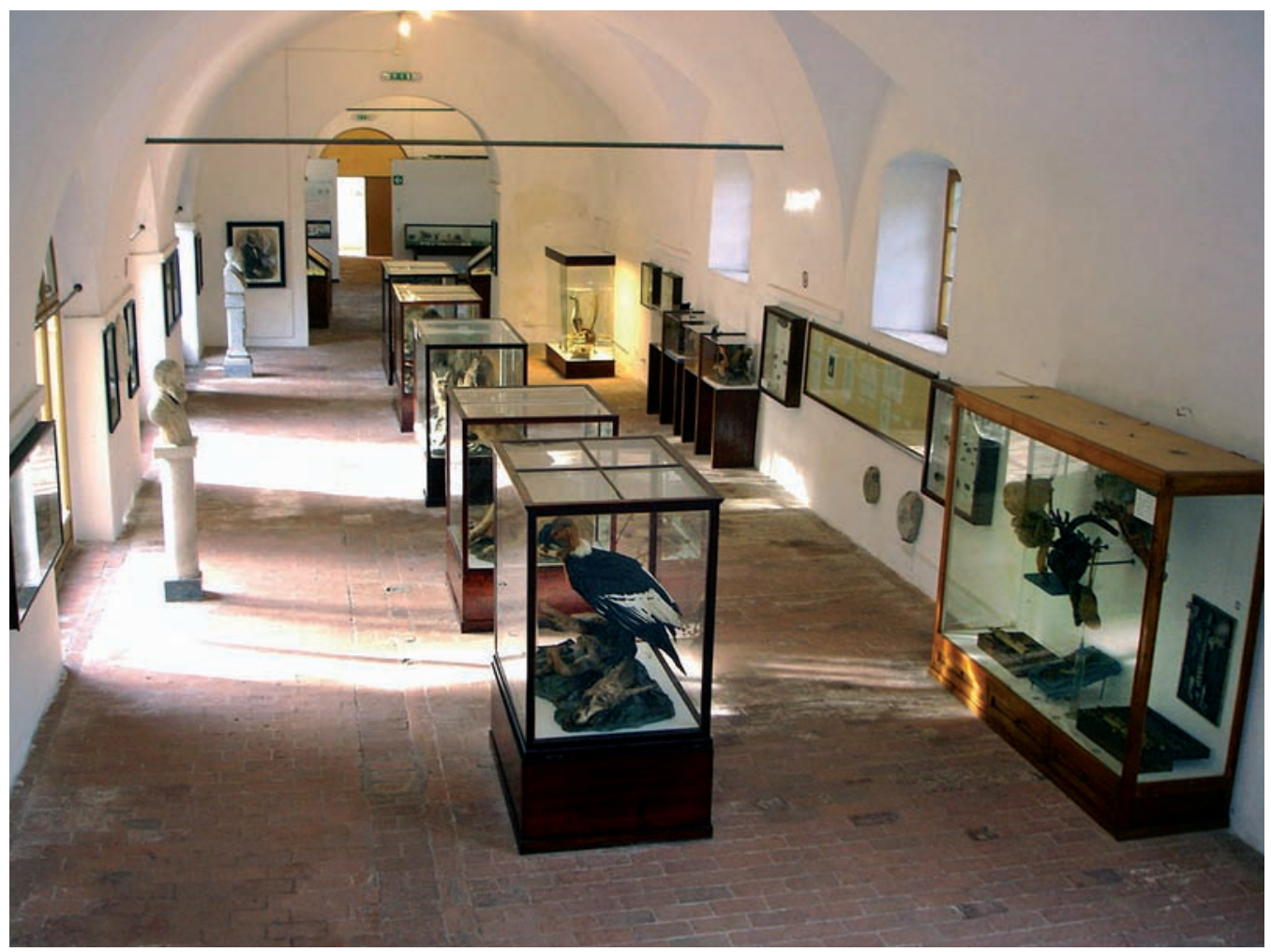

La Sala Storica. Photo: The author.

stuffed birds and reptiles from the 18th and 19th centuries. The large tableaux dominate the hall, which resembles a mix between a sculpture hall and the studio of the British animal painter Edwin Henry Landseer (18021873).

\section{THE TABLEAU}

A raging wild boar is fighting two dogs. Its face is smeared with blood, its neck is pierced by a spear. The spear is broken and blood is running from the wound. Its anus is dilated; we are seeing the animal at the moment of death. One of the hunting dogs is lying on its back with its intestines spewing out; its belly ripped open by the painfully sharp tusks of the wild boar. The other dog has sunk its teeth in the wild boar's ear.

We do not want such repulsive scenes in today's natural history museums, where hunting and natural science have long since taken separate paths. The wild boar tableau is nevertheless displayed to the public because it is both old and demonstrates excellent craftsmanship. The taxidermist has shaped the animals with a plasticity and anatomical accuracy that were unique for the time. This is one of the oldest dioramas to have been preserved in European museums (Zuffi 2008: 195ff).

The brass sign on the display case offers some 


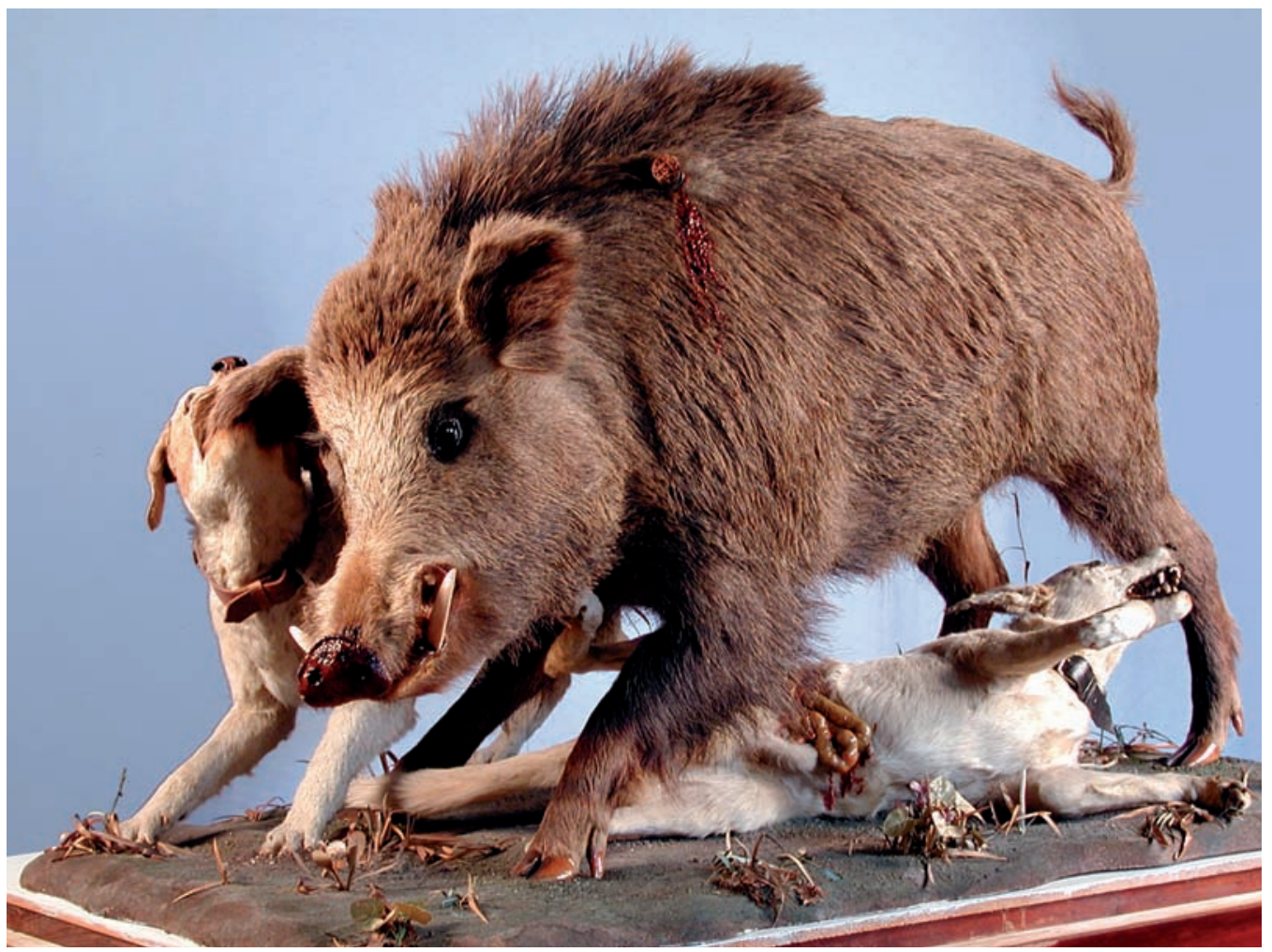

The wild boar tableau. Copyright: Museo di Storia Naturale e del Territorio. Photo: Silvia Battaglini.

terse factual information about the specimen's past history: "Cinghiale e cani (Sus scrofa L. 1758) Esemplare uccisa nella tenuta di San Rossore nel 1824." ${ }^{2}$ No information is given on the provenance or the breed of the two hunting dogs. However, the taxidermist has assigned them roles with a dramatic effect far beyond that of mere extras. The wild board was killed on the property of San Rossore. San Rossore is an old cultural landscape northwest of Pisa, and the area has always belonged to the regents of Tuscany. ${ }^{3}$ This was the private hunting ground of the Medici family from 1535 to 1738 , when the Habsburg-Lothringen house inherited the Grand Dukedom of Toscana. In 1861, San Rossore became the property of the royal house of Savoy, and from 1945 the property has been owned by the Italian state. The area was opened to the general public in 1979 .

\section{KICK OFF}

I will start with the wild boar tableau and its ability to amaze and capture the viewer's attention, an immediate sensory perception that peaks our curiosity. To the degree that materiality speaks, what is the speech of the wild boar? According to the science historian Lorraine Daston, objects that speak are what she calls chimeras. A chimera is a being composed of parts from different animals. Originally a Greek 
term, the chimera was half lion and half goat, with a serpent's tail. ${ }^{4}$ The key aspect about chimeras is that, in Daston's words, they "straddle boundaries between kinds" (Daston 2004: 21), or they straddle boundaries drawn between classes or species. They thus transcend boundaries and connect elements. Because chimerical objects challenge boundaries and categories, they attract attention. Daston maintains that chimerical objects bind materiality and meaning together (Daston 2004: 10). She also claims that the speech of objects is derived from the particular characteristics of the objects, properties that fit with the cultural purposes they are part of and participate in, or participated in. Hence, we must know the context to make things speak. Stuffed animals are chimeras. As physical natural history objects they can be touched, moved, rebuilt and viewed, all according to the purpose. As natural history representations, they tell about fauna and also mobilise perceptions, narratives and emotions. The stuffed animals resist standard classification according to the nature-culture dichotomy. They raise the question of what kind of artefact we are dealing with, are they cultural objects, natural objects or rather hybrids that interact between nature and nonnature, where non-nature points towards the social and cultural conditions of natural science, as well as toward art and notions about the relationship between people and animals.

The Norwegian philosopher Dag T. Anderson also discusses the importance of moving between and across boundaries rather than drawing up boundaries when mapping out the nature of objects. Very often things will move between nature and culture, and this applies to common things as well as objects of art. When thinking about objects we should use this tension as our point of departure. In his essay "I tingenes mellomrike" (In the middle realm of objects) he writes:

A querying introduction to "the philosophy of objects" must consider it as a primary task to ask questions about the fruitfulness of the traditional dividing line between nature and culture. In the day-to-day use of the term and in the orderings and listings of the things daily life operates with, natural objects and cultural objects move quite freely from one order to the other. (...) When the things are examined as manifestations of civilization and culture, a more detailed study will, of course, instantly see that the products of civilisation and culture continuously bring an element of nature with them, however processed it might be. The boundary between cultural objects and natural objects will therefore in many cases necessarily be in flux (Andersson 2001: 132f).

Both Daston's and Anderson's approaches to objects and materiality strain the attempts to sort and order objects into unambiguous categories, and this helps to explain why objects so often resist such categorization. As Andersson puts it, "A fully comprehended object will immediately lose its scope and shrivel into a concept" (Andersson 2001: 131).

A picture will be interpreted in a number of ways according to who sees it and in which time period. The British art historian Martin Kemp claims that one of the tasks of the art historian is to place a picture in the context it was made to understand how it was seen and understood in its contemporary period (Kemp 2007: 9). Paolo Savi's wild boar tableau may be interpreted as a sculpture, a threedimensional scene from the iconography of hunting which gave meaning to the contemporary viewers. As it has been on display in a natural history museum, it is reasonable to claim that the purpose has been to present 
knowledge about the wild boar in nature, displaying the animal whose Latin name is Sus scrofa But wild boar hunting as well as biological knowledge about the wild boar have changed after the tableau was put on display. Below I will show the wild boar as it may have been perceived by contemporaries and link this to how it may be seen today.

\section{THE LOCATION}

La Certosa di Calci, the former Carthusian monastery which is now the seat of the Museo di Storia Naturale e del Territorio, lies on the outskirts of the village of Calci at the foot of Monti Pisani, about ten kilometres east of Pisa, and it has a history that can be traced back to $1366 .{ }^{5}$ Having natural history exhibitions in a monastery facility is unexpected but effective. Mammals, birds, reptiles and minerals have occupied the monastery's financial buildings. The historical specimens are on display in the building where the olive oil press once stood, and the whale skeletons are exhibited in what was once the barn. ${ }^{6}$ The placement is both spectacular and curious: Skeletons of whales, several caught in Norwegian waters, displayed in an olive grove in Tuscany. Certosa di Calci was a closed community where the monks lived in strict separation from the surrounding world. The cells were situated in a number of small houses placed behind the large monastery building and church. Here the monks would spend their days in prayer, preparing food in their cells and sleeping and working there. Today these cells are museum storerooms, and the rest of the monastery facility has been reshaped into exhibition halls and offices. A walk among stuffed animals, skeletons and minerals is thus both an introduction to natural history, the history of natural-history collections and the monastery.

The transfer of the natural-history collections from Pisa to Calci broke with a collection-history tradition that can be traced back to the 1500 s. In 1543 , the doctor and botanist Luca Ghini was given the assignment by Cosimo 1 Medici to construct a "giardino dei semplici," a garden for the cultivation of medical herbs. ${ }^{7}$ Since this was the world's first botanical gardens with a university connection, Ghini could lecture on practical medical botany, and then take his students and show them live plants in the city. Two years later he was given the assignment to construct a similar garden in Padova. In contrast to what happened in Pisa, the original facility in Padova has been preserved and is now on UNESCO's world heritage list (Minelli 1995: 9). In Pisa, the botanical garden was moved to its current location in 1591. The move was completed in $1595,{ }^{8}$ the same year Ferdinando I de Medici decided to transfer a selection of specimens from the ducal collections in Florence to Pisa. The natural-history collections were exhibited in Galleria Pisana. This building is close to the botanical garden, and the two institutions functioned as one complete scientific environment until 1814. Then natural history teaching was divided between two university chairs, one in botany and zoology and one in palaeontology and geology, but physically the natural-history collections remained in the same premises until they were moved to Calci in 1981, which is where we meet the wild boar today.

\section{THE MAN}

On 17 April 1872 a group of students were gathered in the Botanical Garden to unveil a 
marble statue of their highly renowned teacher, Paolo Savi (1798-1871). Savi had been the director of Museo di Storia Naturale in Pisa between 1823 and 1840 . Over the course of these years, he made the museum into one of Italy's most recognized natural science institutions, and he also made it internationally wellknown. In the same year Savi became the museum director, he was also appointed professor of zoology, and zoology and geology were his most important fields. He also taught comparative anatomy. In 1839 he convened a meeting called "la Prima Riunione degli Scienziati", the first national meeting for Italian scientists, 22 years before the kingdom of Italy was proclaimed on 17 March 1861. ${ }^{9}$ As a young man, on assignment from Grand Duke Leopold II, Savi mapped out Tuscany's fauna and geology to provide an overview of its natural resources (Tosi 2008:210). The findings from the geological field studies were published in the two-volume work Mineralogia Toscana. The general public is probably more familiar with Ornitologia Toscana, which was published in four volumes between 1827 and $1851 .^{10}$

At the unveiling ceremony, Achille Ballori stated that Savi had not only excelled as a learned scientist but also as a very gifted artist (Ballori 1872:13). Savi's art was in stuffing or naturalising animals, and when Ballori chose to compare the preparation of animals with an artist's work, he used a characteristic we can follow through the history of modern taxidermy. Stephen Christopher Quinn, for example, characterises the habitat dioramas in the American Museum of Natural History as "the superb examples of the fusion of art and science" (Quinn 2006: 6).

Taxidermy was developed into a refined craft that was in great demand during the Victorian period. Interestingly, the majority of Paolo Sa-

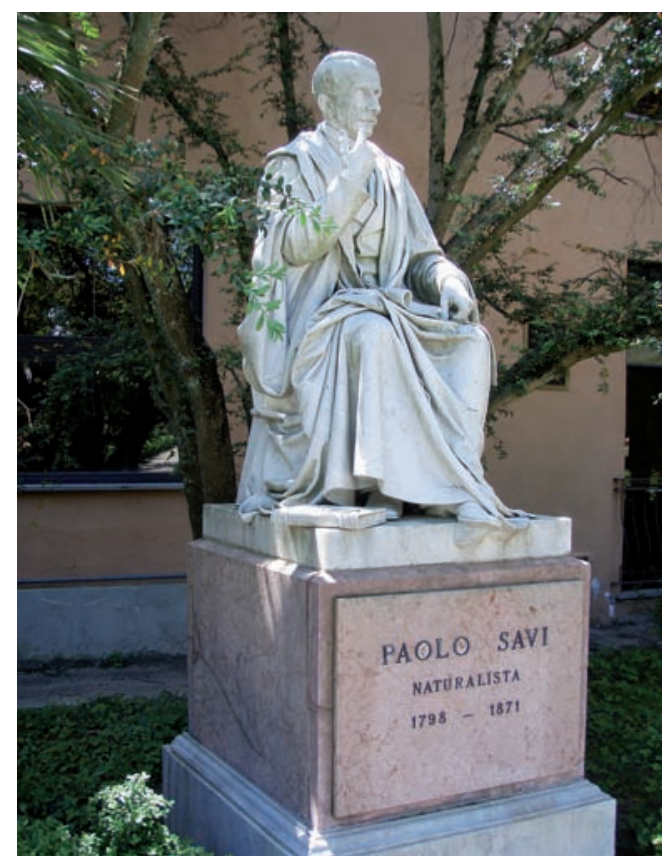

The statue of Paolo Savi unveiled on 17 April 1872. Photo: The author.

vi's taxidermy works was carried out as early as 1820 s, and these works were acknowledged in contemporary Italy and in Europe, where they were displayed at some of the world exhibitions. ${ }^{11}$ Even in 1900, some of Savi's specimens received awards at the Paris world exhibition (Strumia et al.: 2002: 110). It is worth noting that this was the same year that the Field Museum in Chicago bought Carl Akeley's large diorama "The Four Seasons", where for the first time he used the dermoplastic method of casting the animals in papier mâché. This method revolutionised the craft of taxidermy. ${ }^{12}$

Savi was an excellent scientist, but in this discussion he is interesting primarily as a taxidermist. ${ }^{13}$ His taxidermy works show that he used 
resources from research, fieldwork and hunting, while he also had an aesthetic sense and understanding of what the public liked. A gifted taxidermist must have knowledge of animal anatomy and ethology. He must know how to skin the animal, how to prepare hide, fur and feathers, and not least, how to recreate the animal so it is as lifelike as possible. Savi's scientific background and the practical experience he gained as a hunter prove that he must have had detailed familiarity with animal anatomy - particularly animals he hunted himself. Some meticulous pencil drawings of intestines from mammals have been ascribed to Savi, and show that he was a competent artist. ${ }^{14}$ In an unpublished manuscript, Savi writes in detail about how to proceed to collect and prepare birds with the best possible results. Here he instructs on how the bird should be caught and killed as painlessly as possible so that the feather coat will not be damaged, he states how the dead bird should be kept and handled during the fieldwork and he explains how to skin the bird so that the feathers will not be damaged. ${ }^{15}$

\section{A PLATYPUS FOR A CAMEL}

How did one obtain a Bengal tiger, or a condor for that matter, for a European museum in the 1820s and 1830s? The exotic animals in the large tableaux were not collected in their natural habitats on the initiative of the museum. The notice on the display case for the Bengal tiger offers this information: "Tigre del Bengala. (Panthera tigris L. 1758). Livorno, 10 settembre 1836, maschio." The tiger, most probably in the form of a hide, may have come to Livorno on one of the many ships that would arrive in this important port. The notice on the display with the lioness is even terser: "Leonessa (Panthera leo L.1758) e anti-

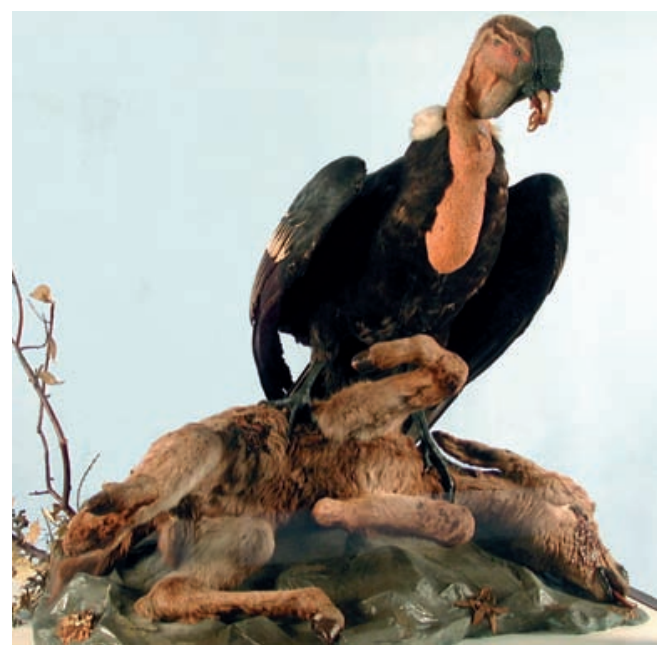

Condor. Copyright: Museo di Storia Naturale e del Territorio. Photo by Franco Strumia.

lope. 6. Aprile 1830". Here the provenance is lacking, but it is probable that Savi bought or traded so-called "flat" specimens, i.e. hides. With the development of the world trade infrastructure and imperialism, new regions were opened for European collectors early in the 19 th century. ${ }^{16}$ Pieces of nature were carried across oceans to European ports and sold to museums and private collectors.

Personal relations opened for exchange of knowledge and natural objects. In 1826, Savi corresponded with Stefano Moricand who was the secretary for the Museum d'Historie Naturelle in Geneva. The correspondence shows that he was looking for specimens of European birds and exotic animals. In June 1826, he bought a platypus from the Swiss for "Franchi 80", and he obtained the hide of a three-fingered pangolin and a damaged musk ox hide in exchange for birds. ${ }^{17}$ The platypus turned out to be a disappointment as the hide proved to be sloppily stitched together from 
the hides of several animals, and he felt that the museum had charged too much. ${ }^{18}$ In return, Savi was able to offer minerals and birds, all in excellent condition and often mounted, and camels from San Rossore, identified correctly by Savi as Arabian camels. ${ }^{19}$ In a letter dated Pisa 12 March 1826, Savi wrote to Moricand that since the Arabian camel hide that was sent to the museum was damaged, they would not need to pay for it: "So far it has not been possible to obtain a new Arabian camel hide. All are very healthy, and as I already have promised you, the first one to die will be for your museum." If there was a shortage of Arabian camels, Savi could offer a completely prepared porcupine, admittedly small, but in good condition - for example in exchange for "an exotic quadruped". He had prepared the porcupine because his experience indicated that a porcupine had to be stuffed immediately while it was still "fresh". ${ }^{20}$ On 18 April, he reported to Moricand that even if two camels had fallen sick, neither was yet dead. ${ }^{21}$ The situation was unchanged two months later: "Still no Arabian camel has died, which I am very sorry for since I most strongly wish to pay my debt to the museum as quickly as possible." He also proposed that if the museum was interested, it could take minerals in exchange. ${ }^{22}$ When finally a camel died in May, it was unusable as it had already been clipped, "as they all are at the end of spring."

In August 1828, Savi went on a study trip to Switzerland and France with two purposes in mind. First, he wished to acquire "produzioni naturali" for the museum. Second, he wanted to study the species of bird he was intending to describe in volume II of his ornithology. In the summer of 1830 , he was travelling again, this time to study the museums in Munich, Dresden, Berlin, Prague and Vien- na. ${ }^{24}$ The condor now exhibited in Sala storica is an adult male bought in Geneva in 1828. ${ }^{25}$ There is no mention of the condor in the letters Savi wrote to Stefano Moricand in 1826. However, it is most likely that Moricand had given Savi a tip about where condors could be found in Geneva as the Museum d'Historie Naturelle had received a condor, registered in 1826. This was a bird not yet fully grown, which had first been stuffed and later disassembled in 1926 to study the skin. ${ }^{26}$ Savi actually managed to procure an adult male.

Among Savi's papers found after his death, there is an undated list labelled "Indirizzi di Persone che si occupano di Storia Naturale ovvero che ne fanno commercio" - a list of addresses of persons occupied with natural history or who earned money from it. ${ }^{27}$ Savi also corresponded with scientists in a number of European countries. Natural objects were traded in a network that included professional nature historians and dedicated amateurs, museum scholars such as Stefano Moricand in Geneva and Geofrey St. Hillaire in Paris, and enthusiasts such as Ferdinando Luciani, "Spesiale (sic!) a Castel nuovo di Val di Cecina". Luciani had sent many nests with adult birds to Savi and was "animatissimo per la storia naturale". ${ }^{28}$ We see that Savi's strategy for building up the collection beyond what he himself collected during his fieldwork in Tuscany was to trade, buy or receive specimens as gifts, a type of "second-hand" trade in dead animals, and a common way of extending collections before the European and American natural-history museums started dispatching their own collection expeditions (Kohler 2006: 107). This means that while Savi surveyed and mapped the local stock of birds, he also organised collections on a grand scale in the form of exchanges between his museum, 
other European museums and private collectors. Birds, porcupines and camels left Pisa to be replaced by specimens of reindeer, bear, zebra, howler monkey, platypus, anteater, beaver, hyena and flying squirrel. The animals were then shaped by Savi and his assistants Pacini and Studiati before being put on display for an enthusiastic public (Strumia et al. 2002: 106f)..$^{29}$

Robert Kohler states that discussions arose in Europe around 1850 on whether to split the collections into a didactic section, consisting of mounted animals, and a study section, consisting of hides and bones (Kohler 2004:108). In the Natural History Museum in London, this principle was first introduced by William Flower who was the director of the museum from 1884 to 1898 (Stearn (1981) 2001: 75f)). Paolo Savi belonged to an older generation of natural historians who did not distinguish between didactic and scientific specimens. A stuffed animal was thus both a scientific object and a natural history representation, and zoological knowledge could equally well be represented by means of taxidermy as through language. It was also clear that taxidermy invited interpretations that moved an animal beyond the genre boundaries of natural history and into the narratives of cultural history. When Savi mounted his animals he was never, as claimed by Ballori in his memorial speech, a slave of any system, but let himself be guided by his talent. The expression varied according to the animal he was preparing. This made his works unique compared to even the very best taxidermists in Italy and abroad (Ballori 1872: 13). It is this dual approach to natural history that invites a comparison between Savi's Tuscany ornithology and the stuffed specimens he made, particularly the wild boar tableau.
SPEAKING TO THE EYE

"Speaking to the eye beyond speaking to the brain I would think would be of the very greatest benefit for my readers," Savi writes in the introductory chapter to Ornitologia Toscana. ${ }^{30}$ Sadly, the historical archives were lost when the museum collections were moved to Certosa di Calci, but there are sporadic hints that show how Paolo Savi thought about presenting natural history, depending on whether the medium was written or visual, a book or an exhibition.

The Age of Enlightenment and its interest in the natural sciences promoted new expertise in connection with natural history illustrations. Correct illustrations of animals and plants demanded close cooperation between the scientist and the artist, "leading to the recognition of the new profession of "naturalistic illustrator" (Tosi 2008: 148). There was great interest in the naturalistic illustration in Tuscany during the first half of the 1800 s (Tosi 2008: 148), and Savi's taxidermy works must be viewed in light of this wish to present a correct visual impression of animals and plants based on empirical studies in the field. In the preface to the first volume of Ornitologia, Savi makes very critical comments on earlier ornithological works. He states frankly that the artist behind the illustrations in Storia Naturale degli Uccelli from 1762 "had never studied the natural movements of the birds he drew," and "was only led by picturesque imagination." ${ }^{11}$ Storia Naturale degli Uccelli is the largest Italian ornithology work published after Aldrovandi's Ornithologia, sive Avium Historia (1599-1634). For his part, Savi chose another method of illustrating his work. He borrowed where he found quality, which was in the British artist and natural scientist Tho- 
mas Bewick's richly illustrated History of British Birds (1797-1804).

The encounter with Bewick's birds inspired Savi to use figures in his own ornithology, even to the point of copying some of the British artist's woodcuts. But they are not exact copies. Francesco Torri's woodcuts in Ornitologia Toscana have been carved with a far rougher technique, and the birds are reversed in relation to Bewick's woodcuts. They also lack the references to British landscapes and buildings, important details that made the starling and the crow into British birds. When Land Birds was published as the first volume in Bewick's ornithology, readers were enthusiastic about how his woodcuts "showed the distinct 'personalities' of different birds", Jenny Uglow writes in her Bewick biography (Uglow 2006: 262). By removing the idiosyncratic elements, Bewick's compositions were adapted to an Ita-

Thomas Bewick: Starling. From History of British Birds.

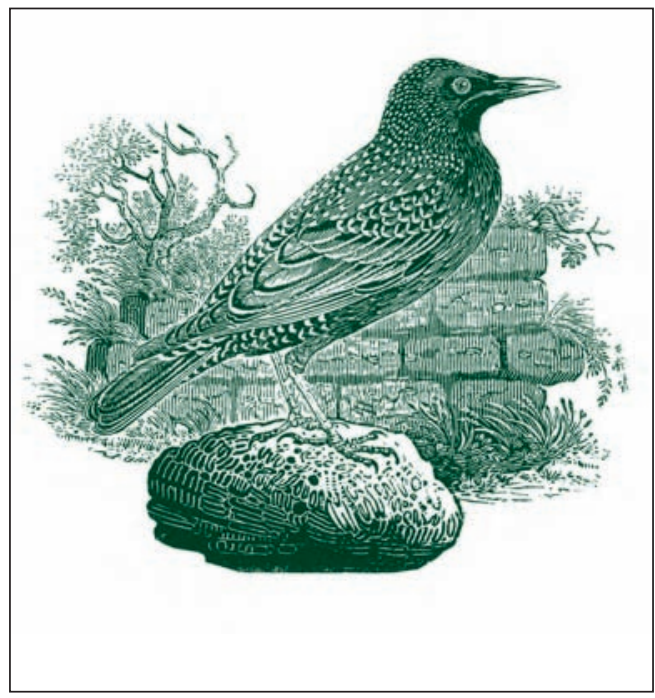

lian ornithology. ${ }^{32}$ The specific was removed in favour of the general so that the attention was drawn to species and family. We see this most clearly in illustrations where it is evident that Bewick has drawn after models of stuffed birds, which already have been transformed into natural history specimens. A good example is Sturnus vulgaris. If we compare Bewick's illustrations with Torri's copies, we immediately notice that Bewick presents the birds as individualising portraits, while Savi's ornithology shows species representati-ons. ${ }^{33}$ The illustrations in modern ornithologies are designed to determine, identify and classify. They function as a visual extension of the written description of the species, which forces the artist to standardise and remove individual characteristics.

Even if the illustrations in Ornitologia Toscana were to speak to the eye, they are only a

Francesco Torri: Starling. From Ornitologia Toscana.

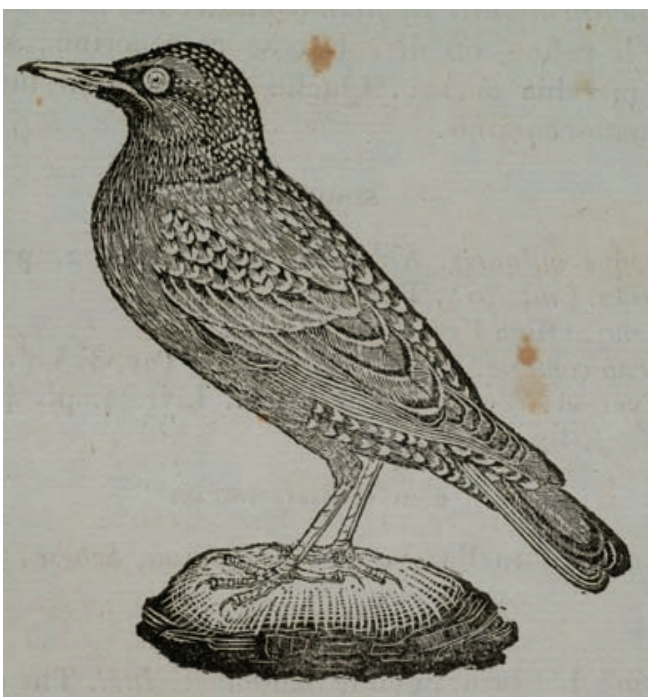


supplement to the text. The ornithology was, as Savi pointed out, "a descriptive work, not an iconographic one.” (Savi 1827: XII ). The opposite must be said of Bewick's History of British Birds, where the success of the books was not least due to their illustrations. As a natural scientist, Bewick was an amateur with a deep knowledge of animals and landscapes. By profession he was a book illustrator, and the prints in the History of British Birds fully show how eminent he was as a woodcarver. The illustrations and the vignettes are small works of art in themselves. As Bewick used the cross end of the wood, his illustrations are small, rarely more than $8 \times 8 \mathrm{~cm}$, and often smaller. ${ }^{34}$ Due to the small format he used the tools of the metal engraver. Bewick's biographer Jenny Uglow points out that the books about land and water birds came at the right time, "since it coincided not only with the growing interest in natural history but also with a thirst for fresh images of the countryside.” (Uglow 2006: 308). Bewick himself lived out his interest as an outdoorsman, observer of nature and artist. At the end of the 18th century and into the 19th, natural history illustration as a genre was renewed in Britain, France and Germany due to a generation of artists who were trained by studying nature in museums and botanical gardens, and who also mastered new reproduction techniques (Tosi 2008: 146). Several of these artists used field studies combined with collection as the point of departure for their works, such as Thomas Bewick and John James Audubon. The History of British Birds became so popular as general reading that Charlotte Brontë would write in Jane Eyre (1840) that Jane hid away with "Bewick on my knee", knowing that this was an allusion that was obvious to her readers (Kean 1998: 47, Uglow 2006: 318). The popularity achieved by the books was not least due to the illustrations where Bewick presented the birds in an environment that also narrated a story. Thus Bewick appears as an eminent representative of "l'artiste savant ou le naturaliste peintre" of the 18th century, the learned artist or the artistic natural scientist who both writes and illustrates his own natural history (Salvi 2002: 153). ${ }^{35}$

History of British Birds became general reading matter. Paolo Savi also wanted to make a reference book that the general public could use. Therefore he chose to write in Italian, not in Latin. This was in accordance with the democratisation of the scientific language which had already been initiated in the preceding generation. The natural historians of the 18th century wrote in the language of their country, which explains why their works became so popular - they satisfied a wide audience by "entertaining as well as instructing" (Thomas 1996 (1984): 282). Savi did not wish to bore the reader. ${ }^{36}$ It was through the text presentation, however, that the reader, generally a hunter, would learn how the birds lived, about their habitat, what they ate, how they flew, where they nested, the shape of the nest and the colour of the eggs (Savi 1827: XII). One of his aims was that the reader would learn scientific terminology. Since hunters would use the nomenclature of their local district, it was a task to "translate" the many local terms into a scientific language, a lingua franca for all bird lovers; a tool that enabled everyone to compare and assess his or her own knowledge with that of others (Savi 1827: XIf). A common terminology was a requirement for compiling ornithological knowledge.

It was obviously a puzzle to assemble and systematize the material for an ornithology. Ornitologia Toscana is based on Paolo Savi's own field studies which spanned a period of 
eight years, ${ }^{37}$ and also on a network of amateurs who sent him birds and information from the districts, and most of all, on the contact Savi, himself a keen hunter, had with other hunters (Savi 1827: IXf). Thus ornithology was part of an established cooperation with bird lovers, professionals and amateurs. Knowledge circulated between the parties, and they all contributed to compiling knowledge about the species of birds in the region (Savi 1827: XIf).

\section{ANIMAL NARRATIONS}

Ornitologia Toscana primarily addressed hunters, and through text rather than pictures. This was not a book for browsing through just to enjoy the illustrations, as the History of British Birds invited the reader to do. The stuffed animals Savi made were something very different: They spoke and continue to speak immediately to the eye and to the imagination. While Savi wrote his ornithology as a guide to the fauna, he used taxidermy to stage it.

In a memorandum from 1838, Savi writes that "the art of preparing animals has now reached such perfection in Museo Pisano that is not easily found elsewhere." According to him, the specimens were made with such skill that not only was the shape preserved but also all the details of the animal, whether the animal was a mammal, bird, reptile or fish (Strumia et al. 2002: 108). ${ }^{38}$ In a pro memoria, written on the occasion of Savi's death, he is praised as the innovator of taxidermy:

The animals which you think look entirely alive reveal the genius of the scientist, and the artist in the master who placed them there. No monotonous rows of hides filled with straw, no shapeless birds with ruined limbs: rather each individual animal alone or in groups in its natural pose, so you almost expect to hear the bird sing close to its sweet nest, the tiger breathe, monkeys jump, snakes hiss, the weak small animals trembling under the claws of their tyrannical enemies. ${ }^{39}$

What techniques did Savi use when he wanted to "speak to the eye"? He writes in a memorandum from 1838 that he wanted to group the animals so that this would show some of their most characteristic habits: “... a wild boar held in one ear by a dog while it has ripped open the belly of another. The wolf that kills the shepherd dog. The lioness holding the gazelle between her paws. The fox cubs surprised while chasing chickens. The wild cat and the hare. The vulture and the cat." (Strumia et al. 2002: 109). The verb "aggruppare", group, is the key term. In contrast to the later habitat dioramas which show the species in their natural environment, Savi made scenes where he played on familiar cultural and deeply anchored matrices or notions on the behaviour of wild animals, and where the wild animals conquer the tame ones. He also designed unique scenes showing motherly love in the world of animals: An opossum female with tiny pups, a squirrel female with offspring, a porcupine with her seven little ones. Such illustrations of animals corresponded to the many educational stories of animals told to children, which enjoyed great popularity during the Victorian period (Griers 2007). Savi also gave the animals poses that break with the conventions for how the species normally have been visualised. One example is the mounting of a reindeer. Stags of the deer family are often mounted with the head held high so that the antlers are displayed prominently. Savi's male reindeer has lain down peacefully to ruminate. 


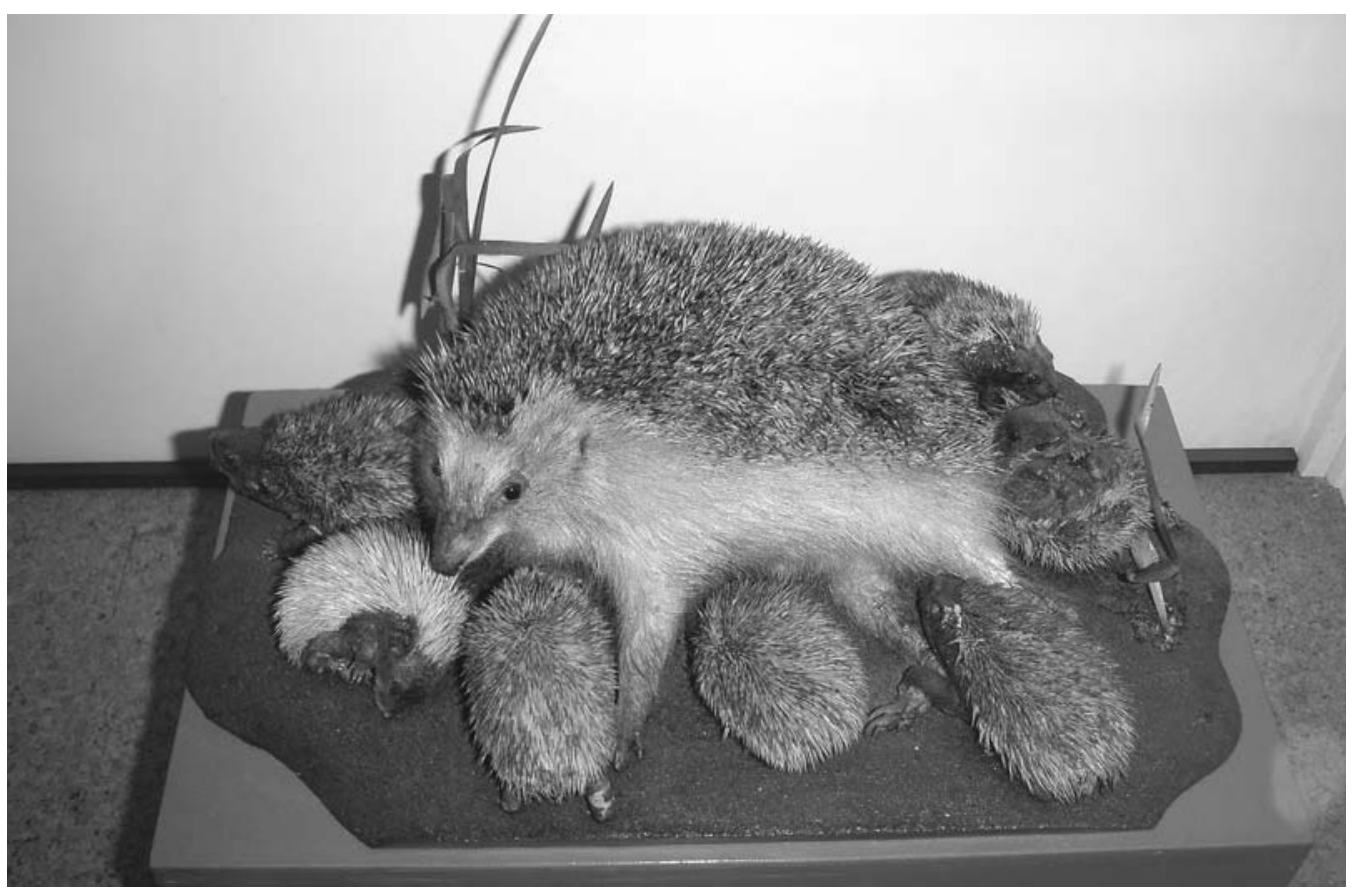

Porcupine female with pups. Photo: The author.

Savi's taxidermy works constitute materialisation of how he has thought about the museum's presentation of natural history. He spoke to the eye using suggestive scenes where the animals were recreated with plasticity and realism the public had never seen previously. He also made them striking by playing on familiar cultural notions, particularly to create attention focusing on animals that existed in the domestic fauna. The mixture of genres is a visual parallel to how natural historians in the same period would spice their books with anecdotes and stories about the animals. Christoph Irmscher designates this manner of writing about nature as "located at the crossroads of Linnean taxonomy and belles lettres, wavering between the demands of precise description and the seductions of the narrative" (Irmscher 1999:8). Savi writes in his ornithology that he consistently enriched it with information about the various birds he described (Savi 1827: XIII). Another well-known natural historian from Savi's generation, the Swede Sven Nilsson (17871883), used anecdotes when presenting the characteristics of animals (Löfgren 1985).

Karen Wonders points out that the taxidermy of mammals invited one into "the animated and narrative style of theatrical, anthropomorphic representation" (Wonders 1993: 24). But rather than inviting one into dramatisation, taxidermy repeated dramatic narratives and visualisations in literature, fairytales, anecdotes and art that the animals had long ago been placed in. Thus, for a period of time, taxidermy ended up promoting established cultural narratives through improved techniques in a new space, the natural history museum. Savi created scenes and plots form which the public's imagination could spin further tales, but which also secured the position 
of popular stories about the nature of animals. The wild boar tableau is a 'tale piece', preferably telling the story about hunting.

\section{THE HUNT}

The wounds that have been inflicted on the wild boar and the dogs are time points in a course of events and add a time dimension to the tableau, both one before and one after what the viewer witnesses. ${ }^{40}$ The course of events links the scene to the long and conservative hunting traditions of European nobility. The wild boar has belonged to kings and dukes - the foremost hunting prey among "la selvaggina nobile stazionale" - the noble stationary prey (Casanova and Guerri 2003, I: 46). The art historian Eric Hobusch reproduces a description of a wild boar hunt during the time of Charlemagne from 799, and he claims that the hunting method described here was practised by German nobility until the 18 th century. The wild boar was first chased by young men on foot, furnished with dogs, spears, nets and hunting horns. After the game had been driven together it was pursued by riders and dogs. The king himself would kill the animal with "his keen sword" after it had been caught and attacked by the dogs (Hobusch 1980: 72f). Killing a wild boar was a tour de force, but hunting wild boar was also a bloody way of bringing more food to the lord of the castle's household. On 12 January 1656, 250 wild boars were killed during a hunt close to Dresden (Hobusch 1980:126). Many dogs were injured and killed during the hunt, and Hobusch states that in 1592, Duke Heinrich of Brunswick kept more than 600 dogs for hunting wild boar (Hobusch 1980: 102).

The wild boar tableau is not about the ha- bits of wild boar, but about those of humans, and it presents the hunt as an animal fight. Violent fights between tame and wild animals have been a popular motif in art and a much appreciated public entertainment. When Paolo Savi made his wild boar tableau, almost fifty years had passed since the Grand Duke's menagerie in Piazza San Marco in Florence was closed on 1 April 1776. Under the Medicis, the menagerie had supplied animals for animal fights arranged at the court, and also served as a zoological garden that the public could pay to visit (Simari 1985). The European upper classes lost their interest in animal fights during the first half of the 18th century, but they continued to be a public spectacle until the first decade of the 19th century. The list of species that had been spurred into attacking each other is long: lions, tigers, leopards, elephants, wolves, bears, wild boars, horses, mules and oxen (Robbins 2002: 71).

Savi placed the wild boar in the hunting regime of the nobility, where the animal was killed by a spear or sword. Even if the status of the wild boar as a hunting trophy was changing around 1820, the hunting scene had not become an anachronism. The history of wild boar hunting in Tuscany reveals changes that are linked to political and property matters, and demographics. Until around 1800, hunting wild boar was a privilege for the nobility, and Tuscany's foremost noble families had their private hunting grounds. ${ }^{41}$ According to Gaetano Riviello, the nobility lost their privileges in areas occupied by Napoleon in 1800, and where French legislation was introduced. This opened for the first step towards democratisation of the hunting of wild boar. The wild boar stock also declined, in part because there were more hunters, and also in part because farmers now had more power behind 
their demands to remove animals, primarily wild boar, that damaged cultivated fields. In this time of change, where the Tuscan bourgeoisie achieve a political and cultural breakthrough, Savi connects his wild boar tableau to a form of hunting that is disappearing ( $\mathrm{Ri}$ viello 2006: 14-19). Was this a tribute to the progressive Grand Duke Leopold II? ?2 $^{2}$

The wild boar was given a symbolic content that was simple to read for an educated public who knew the culture and history of the Tuscan and European upper class. Today's Tuscans see the wild boar with completely diffe- rent eyes. For them, the wild boar is neither a rare nor exclusive animal. The restructuring of the Tuscan agriculture after 1945, with depopulation of villages in higher elevations, overgrowing and forest planting, and stocking the new forests with wild boar, has made the wild boar much more widespread than it was at the time of Savi (Bertelli 2002: 40). At the same time, hunting has been made more democratic through both legislation and organisation. Hunting wild boar is "caccia in battuta", i.e. a chasing hunt with dogs (Casanova and Guerri 2003 II: 101ff). This popular form of hunting

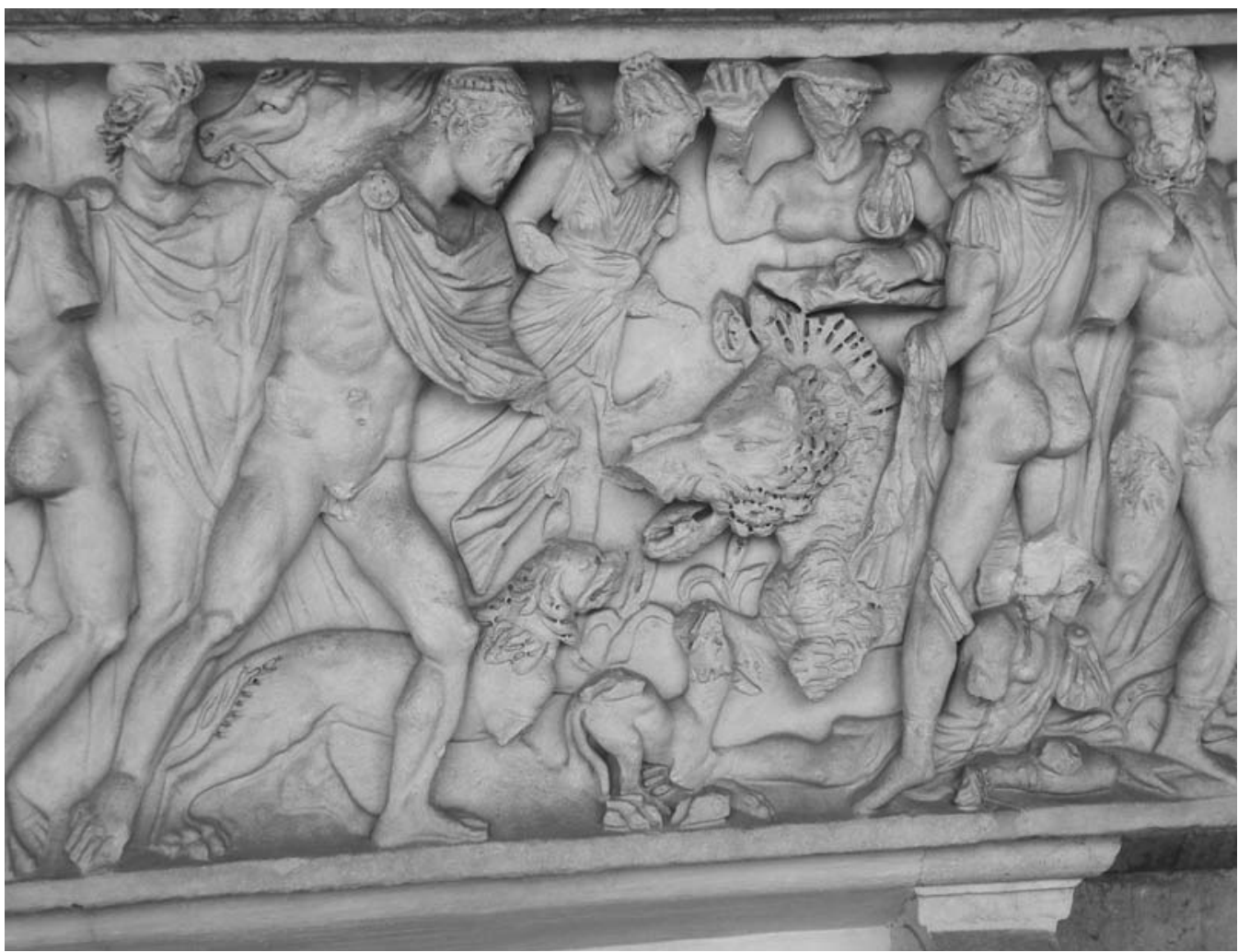


has a long tradition in Maremma, the core area for wild boar in Tuscany, and over time this became the common way of hunting wild boar in Italy (Riviello 2006: 26). In 1976, the wild boar was referred to as the most typical wild animal in Tuscany, and each autumn wild boar dishes will be on the restaurant menus (Bertelli 2002: 40).

Savi played on an older familiar hunt genre he may possibly have participated in himself, which was par force hunting. However, is it possible to specify which template? Savi worked from when making the hunting scene? Here we must turn to art history for further contextualisation.

\section{THE WILD BOAR IN ART}

The wild boar has been rendered in pictures since antiquity. Two famous wild boars and accompanying heroes are featured in Greek mythology: The Caledonian wild boar which was killed by Meleager, and the wild boar from Erymanthos which Hercules chased and captured as the fourth of his twelve heroic deeds.

The wild boar is depicted in paintings and in sculptures, it has found its way into tapestries, wall panels, hunting horns, manuscripts and books, and particularly in the Baroque period, hunting wild boar was a popular motif (Hobusch 1980, Koslow (1995) 2006). The numerous presentations of wild boar hunts reflect the importance of this species in the European aristocracy's display of "conspicuous leisure" (Veblen (1899) 1976). Toscana's most famous wild boar is the one in the fountain $\mathrm{La}$ Fontana del Porcellino, found in La Loggia del Mercato Nuovo in Florence. The wild boar we see here today is the fourth stage of a manifold trading history: A copy from 1988 of Pietro Tacca’s bronze sculpture originally made around 1630. The original has been moved to Palazzo Pitti. Tacca had modelled his wild boar according to inspiration from a wild boar cut in marble, called "Il cinghiale caledonio", the Caledonian wild boar. The marble wild boar is in turn a Roman copy of a bronze wild boar made by the Greek sculptor Lysippos in the fourth century BC. "Il cinghiale caledonio" belonged to the Medici collection in Uffizi, and is now owned by the Uffizi gallery (Koslow (1995) 2006: 154). Beyond Tacca's sculpture there are other links between the marble sculpture and Baroque versions of the wild boar. Peter Paul Rubens and Frans Snyders have both used the wild boar in the Uffizi Gallery as a model for some of their hunt paintings. ${ }^{43}$ The wild boar is interpreted through the expressions of the hunting picture, but it is not the Florentine wild boar which again sticks out its snout in Savi's tableau. Did he choose a Baroque expression because it had appeared on a good model?

Around 1620, the Flemish artist Frans Snyders (1579-1657) painted a wild boar hunt. ${ }^{44}$ Snyders created two new genres: The hunting still life and the so-called pantry picture. Savi was probably familiar with Snyders's work. The painting came to the Uffizi in 1821, two years before Savi started his career with the museum - and the same year the wild boar was supposedly killed. The painting was part of a barter trade between Vienna and Florence, and the large canvas measuring $2.14 \times 3.11$ square meters must have made an impression on the intellectuals and aristocracy of Tuscany. The first printing of the painting was made as early as in 1824 by Lasinio-Gozzini, making Snyders' composition easily available when the wild boar hunt was modelled in the museum workshop.

The Dutch art historian Susan Koslow 


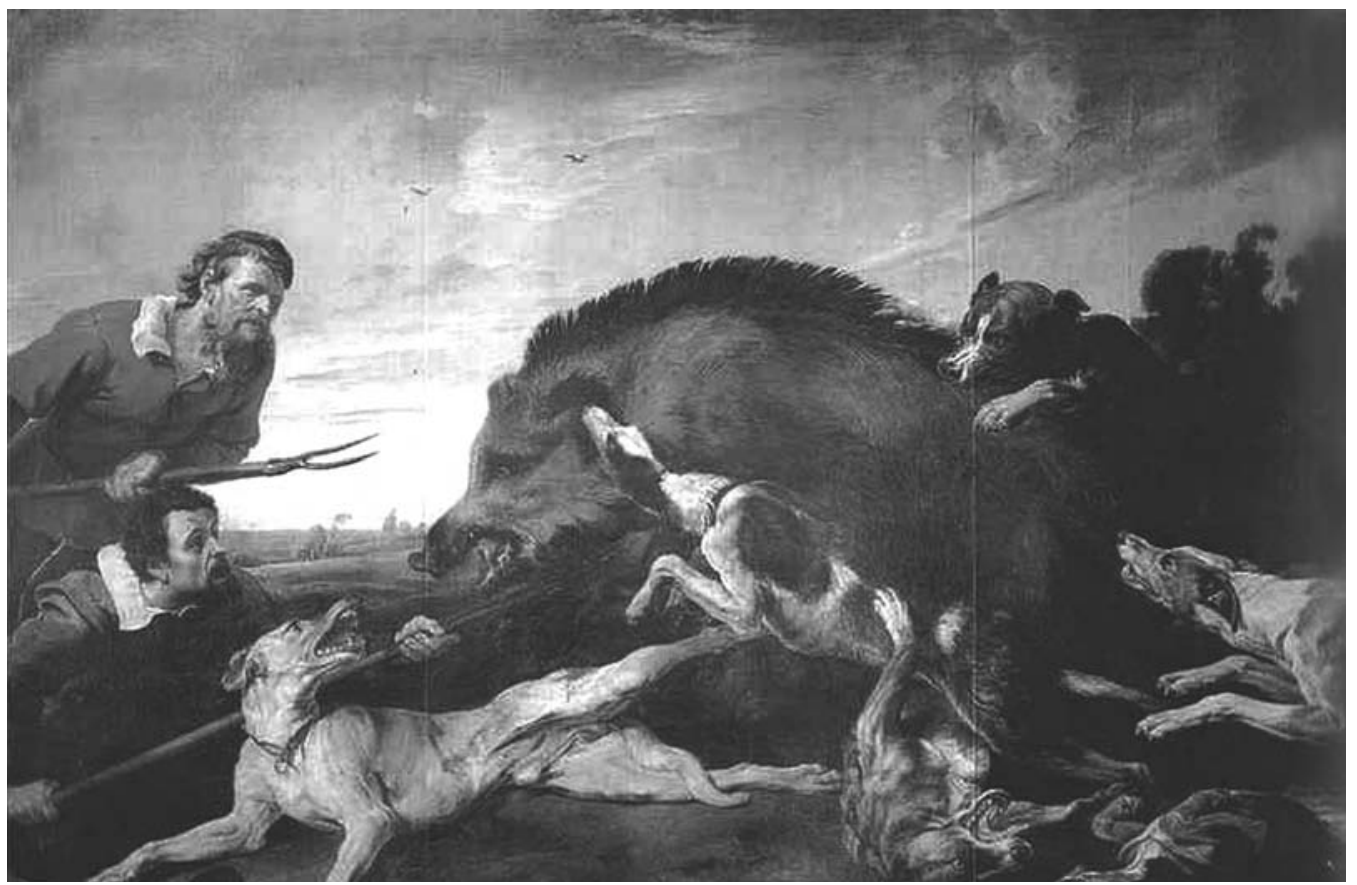

Wild Boar Hunt. Frans Snyders ca 1660. Copyright: Uffizi Galleries.

claims that this is the first hunting picture Frans Snyders painted. She describes it thus:

The moment depicted is the dramatic high point of the hunt, when the bristling boar launches its final assault against its adversaries. Flying forward to escape the bloodthirsty, frenzied pack, it bounds towards the hunters who, awaiting its attack, courageously hold their ground in the face of the beast's fury. The nobleman steadies his pike, anticipating the weight of the raging creature impaled on his weapon. Only a heroic, dying hound separates the two combatants (Koslow (1995) 2006: 221f).

They hunted according to the principle "fur with fur and feather with feather": Animals were hunted using other animals, birds with birds. Koslow refers to a hunting ordinance issued by the Duke of Brabant in 1613 which prohibited hunting with firearms, nets or ot- her mechanical means. The only things permitted were a sword to administer the coup de grace and a hunting horn. Koslow finds the background of the ordinance in the interest of those times in Netherlands' past (Koslow (1995) 2006: 224).

Savi has kept the dying dog and moved the dog maintaining its bite on the wild boar's left ear over to the other side. This he could do because he was working in a three-dimensional format where the animals can be seen from all angles. Snyders generally worked in the frieze format - which means that the wild animal is seen in profile and the hunted animal is in the centre of the picture. In Snyders' interpretation, the wild boar is as big as a lion or bigger - Savi's work is not lying about the proportions. This is also an uncommonly large and powerful specimen. The dogs are small compared to Snyders' hunting dogs which may resemble a cross bet- 
ween a Great Dane and an Irish wolfhound. Snyders's wild boar hunt from 1620 shows both animals and hunters. In later hunting pictures, Snyders allowed the animals to take over the entire canvas. These pictures show the instant when the dogs attack the prey, i.e. immediately before the horsemen reach the fighting animals and before the spear is flung at the wild boar. In Savi's dramaturgy, the spear has been thrown but breaks. The hunters are left behind while the animals storm ahead until they are captured and held at bay in a final battle. Kozlow writes that Snyders's pictures demonstrate that the painter had "precise knowledge of anatomy", and that he "like Rubens, uses anatomical knowledge for expressive purposes: to show strength, endurance and physical anguish" (Koslow (1995) 2006: 229f). When Savi succeeded in transferring a corresponding expression to his composition, he mobilised his knowledge of comparative anatomy, his skills as a hunter and as an accomplished drawing artist.

\section{SUS SCROFA - SMART, AGILE AND DANGE- ROUS}

The wild boar is a border animal which moves between what is wild and what is tame. It has always found its way to cultivated fields and helped itself to the harvest at the expense of the farmers. Wolves took livestock, the wild boar ruined crops. Both have been hated and feared, the wolf more than the wild boar. They are also border animals in the sense that they can mate with tame specimens of the same species, the wolf with dogs, the wild boar with pigs, and have fertile offspring. A third point of similarity between wolves and wild boars is that they can be tamed. The wild boar has been and is an unwanted intruder, and in popular depictions it appears as a bloodthirsty and hyper-sexual animal - particularly old solitary hogs (Padiglione 1989: 98-114). The wild boar has also been considered as the devil's own animal, and a wild boar that had been conquered was a symbolic victory over death (Scheggi 1999: 24f). Because it is a smart, agile and dangerous adversary, it has been attractive to hunt, thus being hunted more as a trophy than as pest.

The precondition for successful hunting is that the hunter is familiar with the habits of the animals he wishes to kill and with their temperament. The theory of the four temperaments, the sanguine, the choleric, melancholic and phlegmatic which worked through a surplus of respectively blood, yellow bile, black bile and phlegm, also included animals. Martin Kemp points out that " $(\mathrm{t})$ he temperaments traditionally attributed to particular beasts, which are themselves built from the four elements, serve to make them ideal representatives of human natures. Thus the fierce choleric must be represented by a bold and combative animal, while a phlegmatic will be equated with a tranquil browser" (Kemp 2007: 17, 20). The wild boar is doubtlessly a choleric. Aristotle wrote about the character of animals that there is no animal with the shape of one beast and its character from another. The short-tempered character of the wild boar is therefore revealed by the stiff bristle covering its body, as, according to Aristotle, "soft hair shows timidity and stiff hair courage". The bravest animals are therefore the lion - and the wild boar (Kemp 2007: 38).

In the life of the aristocracy, hunting had clear similarities with warfare, both practically and symbolically. Hunting meant practising in the use of a weapon while mounted. The prince who hunted wolf and wild boar protected his people against four-legged enemies, 
the wild animals that would trespass on cultivated fields, kill the livestock and threaten people. The wolf was the archenemy, "non c'è nulla che somigli ad una invazione di nemici come l'attacco del lupo", nothing is as like an enemy invasion as the attack by wolves, writes the Middle Age historian Bruno Andreolli (Andreolli in Pietrosanti 1992: 83). The second on the list was the wild boar. The hunt for the wild boar was direct and violent, an antagonistic confrontation between the animal and the hunter, and a form of hunting the prince aristocrat would need to master to be accepted as the foremost among his courtiers (Pietrosanti 1992: 22). Many animals were needed to wage war through hunting. The nobility would exchange rare and beautiful animals, hunting animals, where dogs and falcons were popular exchange objects, and animals that were hunted and were used to stock the sovereign's hunting grounds. Susanna Pietrosanto writes that Tuscany functioned as a virtual game preserve for alien princes; for example in 1493 Lorenzo il Magnifico gave permission to export a female bear and a wild boar which were sent to the Duke of Milan (Pietrosanti 1992: 16). Savi's wild boar is part of this tradition.

The wild boar tableau was one of the objects, actually the biggest, displayed at the exhibition "Sovrani nel giardino d'Europa. Pisa e i Lorena" that documented the scientific and intellectual climate in Pisa under Grand Duke Leopold II. ${ }^{45}$ The zoologist Marco A. L. Zuffi describes the special characteristics of this wild boar thus:

The specimen is a large adult male wild boar, Sus scro$f a$, exhibiting a substantial development of the face, the fleshy and cartilaginous part of the nose, substantial and full gristle on the back, particularly strong on the shoulders and along the spine, and characterised by large dimensions (Zuffi 2008:196).

To a trained eye, these special features reveal that this wild boar was not a common specimen of the wild boar known in the Maremma in Tuscany, Sus scrofa majori, but a specimen of the Central European wild boar which is larger than the Tuscan wild boar, i.e. Sus scrofa scrofa. Then Zuffi adds another dimension to the complexity of the wild boar tableau: The cloven hoofs have a pink tinge. This suggests that this specimen was a hybrid crossbred with tame swine (Zuffi 2008: 196). In Central Europe, the crossbreeding of wild boars with large fleshy tame pigs started at the beginning of the 19 th century to obtain heavier animals. It is known that some Central European wild boar from the period between the wars were set out in Italy several times, and that this type of wild boar is living in several locations in Italy today (Casanova and Guerri 2003 II: 119). In 1821, such a wild boar was nevertheless an imported rarity and an alien element in the Italian fauna (Zuffi 2008: 196). Savi's wild boar is a very large and splendid trophy fit for a duke.

The dogs with their simple leather collars, in contrast, appear small and puny compared to the large hounds that attack the wild boar in Snyders's painting. In the 16th century, two types of dogs were used for hunting, "i bracchi" which tracked the game, and "i levrieri", the hounds which chased and either attacked the game or drove it towards the net so that it could be held fast and then killed (Pietrosanti 1992: 57). Additionally, "limieri" were also used, dogs with handlers that would search through the hunting grounds the day before the hunt and spot where the game was resting or feeding. These dogs search cold tracks, and today short-legged animals are often used for 


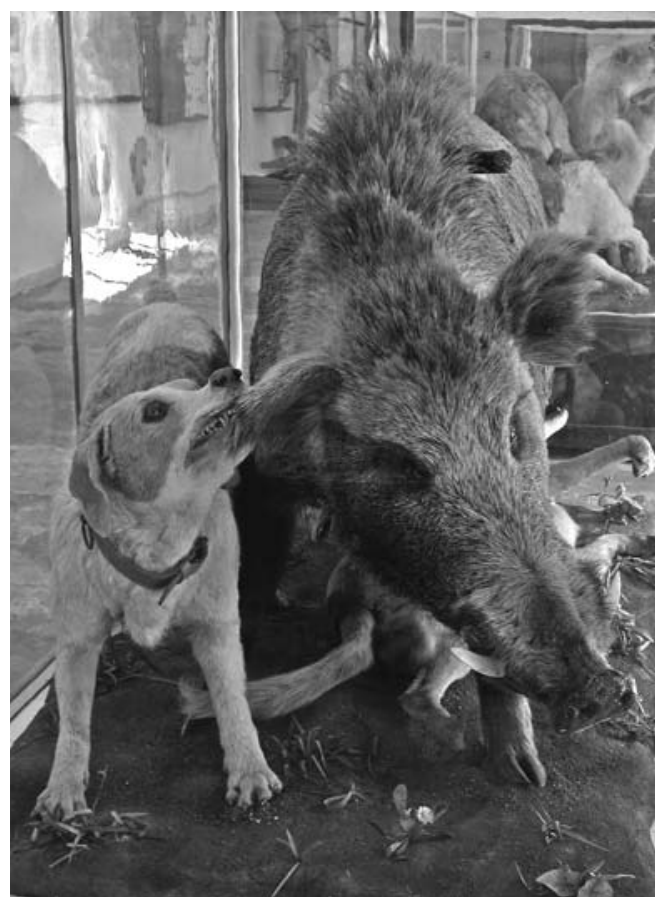

The wild boar in Museo di Storia Naturale e del Territorio. Photo: The author.

this purpose (Pietrosanti 1992: 69). On the other hand, the wild boar stands out even more prominently when the dogs are so small. The hunting dogs of the aristocracy were the result of systematic breeding. These are two street breeds that Savi must have obtained cheaply. The dog biting the wild boar's ear is wirehaired and the tail is cropped. ${ }^{46}$ The wounded dog is smooth-haired and has a long tail. In this way the dogs are also hybrids.

\section{THE GRAND DUKE'S WILD BOAR}

This particular specimen of Sus scrofa has not been naturalised in the sense that it has been made into a natural history specimen. It is still the Grand Duke's trophy, which he has allowed to be naturalised to reserve a splendid and, to Italians, rare specimen of a continental wild boar. The animal, which when alive was an example of how the fauna was cultivated to obtain desirable trophies, thus fulfilled its destiny, and it continued to be exemplary. Stuffed animals can be moved out of and into physical and hence also mental rooms. When the tableau was displayed at the exhibition "Il Giardino d'Europa" in Palazzo Reale in Pisa, it was shown as "Il cinghiale del granduca" The Grand Duke's wild boar. And this is what the tableau speaks about: A prince's hunting trophy which on his command was prepared and displayed in its final rage and mortal fear; not to a closed circle of courtiers, but rather to a curious public in a natural history museum, the odd place where dead animals are collected, stuffed and exhibited.

In the time between 1824, when the specimen was new, and today, the wild boar has moved, both physically and also in terms of meaning. In the same time period, the points tying together natural history, art history and cultural history have become invisible in the museums, and their common references have been blurred. ${ }^{47}$ When the tableau was displayed in Galleria Pisana in 1824, it created enthusiasm because it was new and because it showed an impressive wild boar that mobilised similar images of animals fighting to the death. Today the wild boar is displayed to the public as a historical object requiring attention because it is prepared in a remarkable manner, its age taken into consideration. The tableau's age and quality, not its motif, are guarantors for its continued place in a museum which intends to present knowledge about nature to its public.

To understand this tableau, I have placed it 
in the centre of a network that ties together Paolo Savi, his complex scientific competence and his renewal of Galleria Pisana, his experience as a hunter, and how the wild boar was understood by its contemporaries. What is special about his works is that they testify to both the scientist and the artist Savi. Through the wild boar's provenance of San Rossore I have included the Grand Duke of Tuscany and the type of hunting of the aristocracy in this network to sketch the historical depth of the tableau. The wild boar in history is closely connected to the wild boar in art history and the Dutch Baroque painting represented by Frans Snyders and Peter Paul Rubens. Thus the wild boar steps out of the natural history museum and into art and cultural history collections, not to be placed along Snyders's painting in Palazzo Pitti, but in a context where it becomes less alien and more understandable to today's public.

\section{Translated from Norwegian by Jack Anthony.}

Aknowledgments: I will thank Elisabetta Palagi and Franco Zuffi at Museo di Storia Naturale e del Territorio for their kind assistance; Alessandro Tosi at Dipartimento della Storia dell'Arte, Università di Pisa for inspiration and support; Nigel Rothfels at University Wisconsin-Milwaukee for useful advise; Brita Brenna, Siv Froydis Berg, John Ødemark and Ernst Bjerke, Oslo University for commenting the draft.
NOTER

1. The university website puts the year of the foundation of Università di Pisa at 1338

http://www.unipi.itlateneo/storialstoria.htm_cvt.ht $m$.

2. "Wild boar and dogs (Sus scrofa L.1758). Specimen of male killed in the country property San Rossore in 1824."

3. Tenuta di San Rossore is today part of Ente Parco Regionale di Migliarino San Rossore Massaciuccoli, which together comprises a land area of 24 000 hectares.

http://dizab.uniss.it/Apollonio/aree/rossore/tenuta.htm

4. http://en.wikipedia.org/wiki/chimera_(mythology)

5. http://www.montepisani.com/storia/certosa.htm

6. If not otherwise stated, this section is based on Franco Strumia et al.: Il Museo di Storia Naturale e del Territorio in Paolo Meletti (ed): Arte e Scienza nei musei dell'Università di Pisa. Edizioni Plus: Pisa 2002. 97-141.

7. The term "semplici" designates parts of plants, animals and minerals used in practical medicine (Bedini and Pistolesi 2002:29).

8. http://www.horti.unimore.it/CD/Pisa/Pisahome.html

9. http://www.dst.unipi.it/nascita.htm

10. Paolo Savi: Ornitologia Toscana ossia Descrizione e storia degli uccelli che trovansi nella Toscana con l'aggiunta delle descrizione di tutti gli altri. 4 volumes, 1827, 1829, 1831, 1859. Pisa: Dalla Tipografia Nistri/ Fratelli Nistri. This became the standard work for Tuscan hunters and was re-published in 1959 with a preface by Franco Ceroni Giacometti.

11. "Notevole sono i gruppi di animali imbalsamati da Paolo Savi tra il 1820 e il 1830, che destarono giustificata meraviglia alle Esposizioni Universali dell'Ottocento e che furono ritenuti insuperabili 
dai maggiori musei europei." http://brunelleschi.imss.fi.it/ist/luogo/museostorianaturaleterritoriocalci.htlm

12. On Carl Akeley's works and the dermoplastic method, see Bodry-Sanders 1998.

13. Based on sparse source material, it emerges that professors Pacini and Studiati assisted Savi in making the specimens for the zootomic collection, i.e. animal anatomy specimens (Ballori 1872:15). Excellent animal anatomy specimens can be seen in Museo Veterinario, the Pisa veterinary surgeon museum, and in the collections of Museo di Storia Naturale e del Territorio. Professor Pacini, who is mentioned by Ballori, may have been Filippo Pacini. Pacini was an anatomist, and is later known for having isolated the cholera bacillus in 1854. He was Savi's assistant from 1840 to 1843. http://wikipedia.org/wiki/Filippo_Pacini

14. Apparati respiratori di Mammiferi. Graphite, 20,7x29,5. Dipartimento di Scienze della Terra; Apparati digerenti di Mammiferi. Graphite, 20,7x29,5. Dipartimento di Scienze della Terra. Both cited in Meletti 2002 p.106 and p.107.

15. Paolo Savi manoscritti. Continentore 1, "Savi 2 Appunti di Tassidermia". Dipartimento di Scienze della Terra.

16. Robert E. Kohler 2006: All Creatures. Naturalists, Collectors and Biodiversity, 1850-1950. Princeton University Press: Princeton \& Oxford, 45.

17. Letter to Stefano Moricand from Paolo Savi 6 June 1826. Museum d'Historie Naturelle, Geneva.

18. Letter to Stefano Moricand from Palo Savi 24 July 1826. Museum d'Historie Naturelle, Geneva.

19. The camels at San Rossore were Arabian camels, Camelus dromedarius. In Italian texts they are often called simply camels. The camels at San Rossore have a long history which started in 1622 when Ferdinand II Medici received some as a gift from the Bey of Tunis. These were kept at San
Rossore. Additional camels were also sent here, this time as spoils of war from the Turks in 1683. Nine years later the Medici started breeding camels in Panna in Mugello. In 1738, six Arabian camels were imported from Tunis to enhance the camel breeding in San Rossore, and towards the end of the 1700s the flock counted more than 200 animals. When the German SS occupied San Rossore in 1944, the flock, then counting 68 animals, was massacred. In 1956, four Arabian camels were bought for San Rossore, the last of these died in 1976. Sources: Giovanni R. Fascetti1991: I camelli di San Rossore. Giardini: Pisa; Jacopo De Grossi Mazzorin 2006: Camelli nell'antichità: le presenze in Italia. Achaeozoological studies in honour of Alfredo Riedel. Bolzano. p. 231-242.

20. Letter to Stefano Moricand from Paolo Savi 22 March 1826. Museum d'Historie Naturelle, Geneva.

21. Letter to Stefano Moricand from Paolo Savi 18 April 1826. Museum d'Historie Naturelle, Geneva.

22. Letter to Stefano Moricand from Paolo Savi 5 June1826. Museum d'Historie Naturelle, Geneva.

23. Letter to Stefano Moricand from Paolo Savi 24 July 1826. Museum d'Historie Naturelle, Geneva.

24. Savi speaks about the two trips in the prefaces of Volume 2 and Volume 3 of his ornithology because his study trips delayed the publishing of both these volumes.

25. "Condor delle Ande (Vulptus gryphus L. 1758). Maschio adulto acquistato a Ginevra nel 1828."

26. Catalogue text: "85.057 Le Condor 1 empaillé Perou Mr H. Jurine démonté 1926 (peau)”. Catalogue number MNHG 85.057. E-mail from Alice Cibois 28 January 2009 and from Laurent Valloton 16 February 2009.

27. Paolo Savi manoscritti. Continentore 17," Varia - 
Indirizzi di Persone che si occupano di Storia Naturale ovvero che ne fanno comercio". Dipartimento di Scienze della Terra.

28. Paolo Savi manoscritti. Continentore 17, "Varia 17 - Indirizzi di Persone che si occupano di Storia Naturale ovvero che ne fanno comercio". Dipartimento di Scienze della Terra.

29. Ballori writes that professors Pacini and Studiati helped Savi in making the specimens for the zootomic collections, i.e. animal anatomy specimens (Ballori 1872: 15). Excellent animal anatomy specimens can be seen in Museo Veterinario, the veterinary surgeon museum in Pisa, and in the collections of Museo di Storia Naturale e del Territorio. Professor Pacini, who is mentioned by Ballori, may have been Filippo Pacini. Pacini was an anatomist, and is later known for having isolated the cholera bacillus in 1854 . He was Savi's assistant from 1840 to 1843 .

http://wikipedia.org/wiki/Filippo_Pacini 18.02.2008

30. "Il parlare all'occhio oltre il parlare alla mente, credei dovesse esser della più grande utilità per $\mathrm{i}$ mei lettori, (...)". (Savi 1827: XII).

31. "Il difetto più grande di quelle figure, è nella lor positura strana e forzata. Vedesi chiaramente che il disegnatore non aveva mai osservato le attitudini naturali degli uccelli da lui rappresentati, e che solo lasciavasi guidare da una fantasìa pittoresca.” (Savi 1827: V)

32. The wood carvings after Bewick were made by the law student Francesco Torri. (Savi 1827: XII)

33. See also Tosi 2008:153 about Francesco Torri’s illustrations.

34. Peter Adamson 1996 http://www.standrews.ac.uk/pga/bewick.htlm p.1. By using the end of hardwoods, preferably boxwood, Bewick's blocks became far more durable than older blocks cut into the plank. Bewick introduced a method that was later commonly used. http://en.wikipedia.org/wiki/Thomas Bewick p.1
The durability of Bewick's printing blocks is such that some of them have been used almost one million times without cracking. See Duff HartDavis 2004 [2003]: 94.

35. See also Pamela H. Smith: The Body of the Artisan. Art and Experience in the Scientific Revolution. The University of Chicago Press: Chicago and London 2004.

36. "Per allontanar poi del mio lavoro l'aridità, e monotonìa di semplici descrizioni di parti, e per renderlo più utile e dilettevole che mi fosse possibile, non ho mai trascurato d'arrichirlo delle notizie relative alla storia degli uccelli descritti." (Savi 1827: XIII).

37. "Sono oramai otto anni, che raccolgo, ed esamino gli uccelli, che presso di noi si ritrovano, tanto stazionarj che di passo." (Savi 1827: V).

38. (...) l'arte di preparare gli animali è arrivata nel Museo Pisano ad una perfezione che non è facile il trovare altrove: (...) (Strumia et al. 2002: 108).

39. Alla memoria di Paolo Savi, Pisa 1871, 43; my translation.

40. Thanks to Erling Sandmo for pointing this out.

41. Susanna Pietrosanti writes that the hunting regulations issued by the Medici show that farmers were allowed to hunt wild boar during certain periods, but that they could not afford to hunt in this way that required special weapons, horses and dogs (Pietrosanti 1992:89).

42. It is slightly confusing when it comes to which grand duke the wild boar would pay homage to. If it is correct that it was killed during a hunt at San Rossore in 1821, then it is Ferdinand III. He died in 1824 and was followed by his liberal son, Leopold II.

43. See Koslow (1995, 2006: 227) and the illustrations 298 and 301 on p. 227. In "The Calydonian Boar Hunt" painted by Rubens around 1611-1612, he has copied the marble sculpture in Gli Uffizi. http://www.getty.edu/art/gettyguide/artObjectDetails?artobj=267599 
44. Snyders specialist Susan Koslow puts the time of the painting at around 1620, "certainly by 1620 ", while Gli Uffizi dates it to around 1640 .

45. "Sovrani del giardino d'Europa. Pisa e i Lorena”, Pisa, Museo Nazionale di Palazzo Reale, 20.0914.122008 .

46. The tracking dogs, "i bracchi", have of old had the outermost section of their tails docked (Pietrosanti 1992: 62).

47. See for example Irmscher (1999), Kemp (2007) and Salvi (2002) about the common references and mutual impact of art history and natural history.

\section{LITERATURE}

Andersson, Dag T.: Tingenes tale, tingenes taushet (The speech of objects, the silence of objects). Solum Forlag: Oslo 2001.

Ballori, Achille: Il 17 Aprile 1872 gli scolari di Paolo Savi inauguravano nell'Orto Botanico il busto in marmo da collocarsi nel Museo di Storia Naturale a monumento di affetto e di riconoscienza. Nistri: Pisa 1872: 11-19.

Bedini, Gianni e Guiseppe Pistolesi: L'Orto botanico i: Meletti, Paolo: Arte e scienza nei musei dell'università di Pisa. Edizioni Plus: Pisa 2002: 27-71.

Bertelli, Christa: "Oggi i cignale sa leggere e scrivere". Greentime: Firenze 2002.

Bodry-Sanders, Penelope: African Obsession. The Life and Legacy of Carl Akeley. Batax Museum Publishing: Jacksonville 1998.

Casanova, Paolo e Francesco Sorbetti Guerri: La caccia in Toscana negli ultimi settant'anni. Edizioni Polistampa: Firenze 2003, I, II.

Coppini, Romano Paolo and Alessandro Tosi (ed): Sovrani nel giardino d'Europa. Pacini Editore: Pisa 2008.

Daston, Lorraine (ed): Things that Talk. Object Lessons from Art and Science. Zone Books: New York 2004 .
De Grossi Mazzorin, Jacopo: Camelli nell'antichità: le presenze in Italia. Archaeozoological studies in honour of Alfredo Riedel. Bolzano 2006. 231-242.

Fascetti, Giovanni R.: I camelli di San Rossore. Giardini: Pisa 2006.

Grier, Katerine C.: Pets in America. A History. A Harvest Book: Orlando 2007.

Hobusch, Eric: Fair Game. A History of Hunting, Shooting and Animal Conservation. Arco Publishing Books: New York 1980.

Irmscher, Christoph: The Poetics of Natural History. From John Bartram to William James. Rutgers University Press: New Brunswick, New Jersey and London 1999.

Kean, Hilda: Animal Rights. Political and Social Change in Britain since 1800. Reaktion Books: London 1998.

Kemp, Martin: The Human Animal in Western Art and Science. The University of Chicago Press: Chicago and London 2007.

Kohler, Robert: All Creatures. Naturalists, Collectors and Biodiversity, 1850-1950. Princeton University Press: Princeton and Oxford 2006.

Koslow, Susan: Snyders. Fond Mercator: Bruxelles 2006.

Löfgren, Orvar: "Our Friends in Nature”. Ethos, 50. 184-213.

Meletti, Paolo: Arte e scienza nei musei dell'università di Pisa. Edizioni Plus: Pisa 2002.

Minelli, Alessandro (red): L'Orto botanico di Padova 1545-1995. Marsilio: Venezia 1995.

Morris P.A.: Taxidermist to the World. The Lavenham Press: Lavenham 2003.

Padiglione, Vincenzo: Il cinghiale cacciatore. Antropologia simbolica della caccia in Sardegna. Armando Editore: Roma 1989.

Pietrosanti, Susanna: Le cacce dei Medici. Vallecchi Editore: Firenze 1992.

Quinn, Stephen Christopher: Windows on Nature. Abrams: New York 2006.

Riviello, Gaetano: Evoluzione della caccia al cinghiale 
in Toscana. Edizioni Polistampa: Firenze 2006.

Robbins, Louise: Elephant Slaves and Pampered Parrots. Exotic Animals in Eighteenth-Century Paris. The John Hopkins University Press: Baltimore 2002.

Salvi, Claudia: Le Grand Livre des Animaux de Buffon. La Renaissance du Livre: Tournai 2002.

Savi, Paolo: Ornitologia Toscana ossia Descrizione e storia degli uccelli che trovansi nella Toscana con l'aggiunta delle descrizione di tutti gli altri. 4 volumes, 1827, 1829, 1831, 1859. Pisa: Dalla Tipografia Nistri/ Fratelli Nistri

Savi, Paolo: Ornitologia Toscana. Luciano Ferriani Editore: Milano 1959. Preface by Franco Ceroni Giacometti.

Scheggi, Massimo: La Bestia Nera. Caccia al cinghiale fra mito, storia e attualità. Libri di Diana: Firenze 1999.

Simari, Matilde: "Menageries in Medicean Florence." In: Mosco, Marilena: Natura viva in Casa Medici. Centro Di: Firenze 1985. 23-30.

Stearn, William T: The Natural History Museum at South Kensington. A History of the Museum 17531980. The Natural History Museum: London (1981), 2001.

Strumia, Franco et al.: Il Museo di Storia Naturale e del Territorio. In: Meletti, Paolo: Arte e scienza nei musei dell'università di Pisa. Edizioni Plus: Pisa 2002. 97-141

Thomas, Keith: Man and the Natural World. Changing Attitudes in England 1500-1800. Oxford University Press: New York, Oxford 1996 (1984).

Tosi, Alessandro: From Florence to Philadelphia: Naturalistic Illustration in Tuscany, c. 1760-c. 1840. In: Therese O'Malley and Amy R.W. Meyers (ed): The Art of Natural History: Illustrated Treatises and Botanical Paintings, 1400-1850. Yale University Press: New Haven and London 2008. 143-159.

Tosi, Alessandro: Dipingere nel "giardino d'Europa”. In: Coppini, Romano Paolo and Alessandro Tosi (ed): Sovrani nel giardino d'Europa. Pacini Editore: Pisa 2008. 205-221.

Uglow, Jenny: Nature's Engraver. A Life of Thomas Bewick. Faber and Faber: London 2006.

Veblen, Thorstein B.: Den arbeidsfrie klasse (The Leisure Class).Gyldendal: Oslo 1976 (1899).

Wonders, Karen: Habitat Dioramas. Illusions of Wilderness in Museums of Natural History. Acta Universitatis Upsaliensis. Figura Nova Series 25. Uppsala 1993.

Zuffi, Marco A.L.: Il Cinghiale del Granduca. In: Romano Paolo Coppini e Alessandro Tosi (ed): Sovrani nel giardino d'Europa. Pacini Editore: Pisa 2008. 195-197.

*Liv Emma Thorsen, Professor Department of Culture Studies and Oriental Languages, University of Oslo

Address: P.O. Box 1010 Blindern

NO-0315 Oslo, Norway

Phone: +4722854913

Fax: +4722854828

E-mail:l.e.thorsen@iks.uio.no 